ESCRITAS Vol. 9 n. 1 (2017) ISSN 2238-7188 p. 79-98

\title{
"ESSA É A HISTÓRIA NOSSA, DO MEU TEMPO PRA CÁ": MEMÓRIA, POESIA E MARTÍRIO NO DOCUMENTÁRIO EXPEDITO, EM BUSCA DE OUTROS NORTES
}

\author{
"THAT IS THE HISTORY OURS, OF MY TIME FOR YOU": \\ MEMORY, POETRY AND MARTÍRIO IN THE DOCUMENTARY \\ EXPEDITO: FIELD AND POETRY
}

Janailson Macêdo Luiz ${ }^{1}$

\begin{abstract}
RESUMO: Lançado em 2007, o documentário Expedito, em busca de outros nortes, retrata por intermédio de diversos relatos orais de memória e recursos poéticos, musicais e imagéticos, a trajetória do sindicalista Expedito Ribeiro de Souza, assassinado em Rio Maria-PA, em 1991. O artigo problematiza as imagens sobre a vida e a atuação política de Expedito constituídas pelo filme, através da análise de algumas opções realizadas pelos seus diretores e produtores durante a constituição da narrativa. Ao reunir memórias de pessoas que compartilharam dos mesmos espaços vida e de luta de Expedito, assim como efetuar uma apropriação dos rastros deixados pelo sindicalista, a obra se constitui não somente como um importante lugar de memória sobre o legado por ele deixado e acerca da luta pela terra na Amazônia brasileira no contexto da redemocratização, mas autoriza certas leituras sobre a vida de Expedito e ressignificações sobre sua morte, solidificando sua inserção entre os mártires da luta pela terra.
\end{abstract}

PALAVRAS-CHAVES: Expedito Ribeiro de Souza; Documentário; Memória.

ABSTRACT: "Expedito, em busca de outros nortes" is a 2007 documentary film that portrays the Expedito Ribeiro de Souza' life trajectory, a syndicalist assassinated in Rio Maria-PA in 1991, through several oral reports of memory and poetic, musical and picture resources. This article problematizes the presented images, chosen by directors and producers, about Expedito's life and political action inside the film. The documentary brings together memories of people who shared Expedito's life and struggle, as well as making an appropriation of the traces left by the syndicalist. In

\footnotetext{
${ }^{1}$ Licenciado em História pela Universidade Estadual da Paraíba (UEPB) e mestre em História pela Universidade Federal de Campina Grande (UFCG). É professor da Universidade Federal do Sul e Sudeste do Pará (UNIFESSPA). Contato:janailsonmacedo@hotmail.com.
} 
addition, it's an important place of memory about the legacy left by Expedito and about the land conflicts in the Brazilian Amazon in the context of redemocratization. It authorizes some readings about Expedito's life and re-significances about his death what sets him among the martyrs of the land conflicts.

KEYWORDS: Expedito Ribeiro de Souza; Documentary; Memory.

\section{Introdução}

O documentário se constitui como um dos gêneros da produção cinematográfica que mais guarda aproximações com a escrita da história, principalmente por assentar sua narrativa nos chamados efeitos de realidade ${ }^{2}$. Ainda que gozem de uma licença maior para transitar pelos limites entre o que se convenciona distinguir entre realidade e ficção, "evidência e representação" (NAPOLITANO, 2010, p. 281), os documentaristas, assim como os historiadores, também costumam alicerçar suas obras em rastros (GAGNEBIN, 1998) ${ }^{3}$ deixados pelos sujeitos e grupos por eles retratados, mostrando aos expectadores que constituíram suas narrativas a partir de um dado regime de veracidade, que dá as regras para o que se está se buscando documentar.

Ao tomar um documentário como objeto da análise histórica, torna-se importante considerá-lo não somente como um relato sobre determinados fatos, mas também encará-lo como um fato a ser revolvido, descomposto, interpretado. Segundo um dos historiadores que mais se dedicaram a compreender as relações entre história e cinema, um filme "não vale somente por aquilo que testemunha, mas também pela abordagem sócio-histórica que autoriza" (FERRO, 2010, p. 32). Por isso, ao se analisar um documentário ou uma obra ficional, é importante que a produção seja considerada como um objeto que guarda em si as marcas do seu contexto de produção, das intencionalidades de seus produtores, bem como das condições de possibilidade a partir

\footnotetext{
${ }^{2}$ Para Aumont e Marie (2003, p. 92): "O efeito de realidade designa o efeito produzido, em uma imagem representativa (quadro, fotografia, filme), pelo conjunto dos indícios de analogia: tais indícios são historicamente determinados; são, portanto, convencionais ('codificados', diz Oudart).”

3 "Esse conceito de rastro nos conduz à problemática, brevemente evocado, da memória. Notamos primeiro que o rastro, na tradição filosófica e psicológica, foi sempre uma dessas noções preciosas e complexas - para não dizer, em boa (?) lógica cartesiana, obscuras - que procuram manter juntas a presença do ausente e a ausência da presença. Que seja sobre tabletes de cera ou sobre um bloco mágico, essas metáforas privilegiadas da alma, o rastro inscreve a lembrança de uma presença que não existe mais e que sempre corre o risco de apagar definitivamente" (GAGNEBIN, 1998, p. 213).
} 
das quais foi produzido, que se fazem presentes nas representações (CHARTIER, 2002) que auxiliam a instituir acerca de determinados sujeitos e grupos sociais.

Tais considerações se tornam ainda mais importantes quando a produção em análise faz referência a memórias em disputa e a um contexto como aquele em que atuou Expedito Ribeiro de Souza; contexto que na Amazônia oriental brasileira, no final dos anos oitenta e começo dos anos noventa, foi perpassado por tensões, conflitos, negociações e mobilizações relacionadas as lutas pela terra; período que legou fortes heranças aos anos dois mil, momento de produção do documentário Expedito, em busca de outros nortes, onde tiveram continuidade os conflitos envolvendo os sujeitos do campo e a constante ameaça à atuação de integrantes de movimentos sociais e lideranças sindicais ou religiosas comprometidas com a luta no campo.

Expedito foi assassinado próximo a sua residência em Rio Maria, aos quarenta e dois anos de idade, em 02 de fevereiro de 1991, por José Serafim Sales, conhecido como "Bairrerito", jovem pistoleiro que à época contava com 19 anos e cujo funesto serviço havia sido encomendado pelo fazendeiro Jerônimo Alves do Amorim. Mineiro de Governador Valadares, negro, poeta, pai de nove filhos, Expedito atuava como presidente do eleito do Sindicato dos Trabalhadores Rurais (STR) de Rio Maria; sindicato que ajudou a fundar naquele município do Sul do Pará.

Gringo (Raimundo Ferreira Lima), Irmã Adelaide Molinari, Padre Josimo Moraes Tavares, Belchior Martins da Costa, Paulo Fontelles, Brás Antônio de Oliveira, Ronan Rafael Ventura, João Canuto, José Canuto, Paulo Canuto... Foram muitas as pessoas ligadas a luta pela terra que, como designa a categoria geralmente apropriada pelos militantes para retratar o assassinato de seus companheiros de luta, tombaram no Sul e Sudeste do Pará entre 1980 e 1991. Entre os mais lembrados, num contexto onde centenas de posseiros foram assassinados, estão aqueles ligados aos sindicatos rurais e a setores progressistas da Igreja Católica relacionados as Comunidades Eclesiais de Base (CEBs) e que gravitavam em torno da Comissão Pastoral da Terra (CPT) e de uma atuação social e política ligada a teologia da libertação ${ }^{4}$. Sujeitos com uma atuação

\footnotetext{
${ }^{4}$ Para Boff $(2017, \mathrm{~s} / \mathrm{p})$, um dos principais expoentes da Teologia da Libertação, corrente teológica fortemente veiculada no Brasil e na América Latina entre os anos 1970 e 1990, marcada pela aproximação entre fé e política e por uma atuação do que se convencionou denominar como setores progressistas da Igreja Católica junto aos pobres e oprimidos: "a marca registrada da Teologia da Libertação é agora e será até o juizo final: a opção pelos pobres contra sua pobreza e a favor de sua vida e liberdade." Para Peixoto (1991, p. 146), esse modus operandi de determinados setores da Igreja dá continuidade as estratégias missionárias desenvolvidas pela instituição: "a Igreja procura justificar seus tradicionais motivos teológicos através de atitudes contemporâneas. A difusão da fé requer um campo propício, que não o da mais gritante miséria social e permanentes migrações populacionais. Ao lutar para
} 
semelhante a que desempenhava o próprio Expedito, que além de líder sindical, atuava como coordenador das CEBs na Paróquia de Rio Maria.

O assassinato de Expedito, dada a sua relação com o contexto de violência e impunidade que o próprio sindicalista se empenhava em combater e denunciar em diversos locais do Brasil e junto a órgãos internacionais de imprensa, gerou grande repercussão e se tornou um ponto de inflexão no que concerne a luta pela reforma agrária, assim como a cobrança por justiça e pelo fim da impunidade em relação aos crimes do campo; cobrança esta que passou, naquele início da redemocratização, a ser cada vez mais encampada por agentes da sociedade civil brasileira, em destaque a CPT, junto aos poderes executivo, legislativo e judiciário e em contato com entidades internacionais. Como pontuou Oliveira Filho:

O caso Expedito mobilizou a atenção de inúmeras entidades que lutam pela reforma agrária e pelos direitos humanos, entre elas a Anistia Internacional, que definiu Rio Maria como um caso de 'ação urgente'. Dezenas de 'Comitês Rio Maria contra a Violência e a Impunidade' foram criados o Brasil e no exterior, engrossando o coro dos que pedem o fim da violência e da impunidade (1991, p. 16).

A atuação de Expedito e o legado deixado pelas mobilizações após o seu assassinato deixaram como rastro para o tempo presente inúmeros relatos de memória e registros da vida e obra do sindicalista. Por isso, ao tomar o filme Expedito como objeto de investigação histórica, é mister interrogar como a obra se relaciona como esse legado, e como aciona determinados rastros e os fazem dialogar com os expectadores no tempo presente. Torna-se relevante, portanto, problematizá-la a partir do movimento de produção que lhe é próprio, na esteira do proposto por Morenttin (2011, p. 62), para quem o historiador deve buscar, num primeiro momento, "refazer o caminho trilhado pela narrativa e reconhecer a área a ser percorrida a fim de compreender as opções que foram feitas e as que foram deixadas de lado no decorrer de seu trajeto". Ferro, por sua vez, defende que ao tomar um filme como objeto de investigação histórica, este seja observado pelo historiador:

(...) como um produto, uma imagem-objeto, cujas significações não são somente cinematográficas. [...] A análise não incide necessariamente sobre a obra em sua totalidade: ela pode se apoiar sobre extratos, pesquisar 'séries', compor conjuntos. E a crítica

a mudança da política governamental, em favor dos princípios éticos do bem comum, a Igreja não só contribui para a evolução da sociedade, como também se legitima perante esta sociedade para continuar a exercer seu poder autônomo". 
também não se limita ao filme, ela se integra ao mundo que o rodeia e com o qual se comunica, necessariamente (2010, p. 32).

Diante de tais considerações sobre a problematização dos filmes e seus contextos de produção pela história, foram levantados alguns questionamentos que serviram, literalmente, de norte para as interpretações que serão apresentadas a seguir: Que imagens o documentário constitui/autoriza com relação a memória de Expedito Ribeiro de Souza, do contexto de luta pela terra em que ele esteve envolvido e do seu contexto de produção? Que intencionalidades apresenta em relação ao lugar social de quem o produziu e daqueles que busca representar? Que recursos estéticos e técnicos lança mão ao produzir os seus efeitos de realidade e como esses efeitos contribuem para a produção de representações em torno dos sujeitos e grupos retratados?

É importante considerar, como já aludido acima, que muitas vezes durante a produção de um documentário seus diretores costumam apropriar-se de depoimentos produzidos especialmente para o filme, elencados em conjunto com imagens de arquivo e outros rastros deixados por aqueles que estão sendo retratados; o que contribui para não somente documentar, mas também monumentalizar os personagens alvos da representação, sobretudo ao serem alçados ao patamar dos que são dignos de rememoração. Como assinala Le Goff, o documento:

é uma coisa que fica, que dura, e o testemunho, o ensinamento (para evocar a etimologia) que ele traz devem ser em primeiro lugar analisados, desmistificando-lhe o seu significado aparente. $\mathrm{O}$ documento é monumento. Resulta do esforço das sociedades históricas para impor ao futuro - voluntária ou involuntariamente determinada imagem de si próprios (2003, p. 358).

Por isso, ao refazer os caminhos trilhados na constituição da narrativa fílmica, ainda mais se tratando de um gênero que tem justo como objetivo documentar, no sentido de criar um documento com valor histórico, faremos o cotejamento do que é apresentado no documentário com explicações relativas as fontes nele apropriadas durante a constituição de seu arquivo e com compreensões necessárias sobre essas fontes, seus contextos de produção e com os diálogos realizados pela obra. Evidente que não se tratará de uma busca por esgotar as possibilidades de abordagem e interpretação, mas de buscar compreender "o que o filme diz e como diz" (NAPOLITANO, p. 282) em relação as problematizações levantadas.

\section{Lugares de memória da/na luta pela terra: o papel da "Igreja dos oprimidos"}


O documentário Expedito foi dirigido e roteirizado pela cineasta Aída Marques, professora da Universidade Federal Fluminense (UFF), que havia dirigido até então cerca de cento e setenta produções audiovisuais; e pelo professor da Universidade Federal do Rio de Janeiro (UFRJ), Beto Novaes, que desde os anos 1980 desenvolve atividades que objetivam transformar "as pesquisas acadêmicas em linguagem visual, documentários" (NOVAES, 2017, s/p).

Cumpre observar que, segundo o currículo lattes de Aída Marques (MARQUES, 2017), Expedito foi o quinto documentário assinado pela dupla desde 1988; inserindo-se entre produções que tratavam em sua maioria das questões agrárias e da condição de trabalho e vida dos trabalhadores do campo. No currículo de Beto Novaes, por sua vez, é destacado que aquele professor/cineasta têm produzido:

documentários relacionados aos seguintes temas: trabalho infantil, trabalho no agronegócio, saúde coletiva, saúde do trabalhador, migrações, fronteira, resgate memória de lutas sociais no campo e de trajetórias de vida de trabalhadores rurais, condições de trabalho no agronegócio, inovação tecnológica e dinâmicas do mercado de trabalho agrícola (NOVAES, 2017, s/p).

Os lugares sociais ocupados por ambos nos ajudam a compreender o desenvolvimento do documentário Expedito. Ainda no que se refere ao currículo de Novaes, podem ser encontradas informações pertinentes ao projeto de pesquisa que originou o documentário, desenvolvido entre 2004 e 2006 e intitulado Amazônia Brasileira: poesia e tragédia na luta pela terra. A história de Expedito Ribeiro de Souza. Outros agentes envolvidos diretamente com a elaboração do documentário são apresentados como integrantes do referido projeto de pesquisa, a exemplo de: Rosilene Alvim (produção); Adonia Prado (produção, consultoria e pesquisa); e Ricardo Rezende, nome que dada sua relação com o contexto de atuação da Igreja Católica na região do Araguaia-Tocantins não poderia passar despercebido.

O mineiro Ricardo Rezende Figueira habitou o Sul do Pará entre 1976-1996, onde se ordenou padre e se constituiu como uma das figuras mais destacadas no cerne da atuação da Igreja Católica na regional da CPT Araguaia-Tocantins, tendo sido, junto com Expedito, uma das pessoas inseridas na lista de marcados para morrer que circulava em Rio Maria no começo dos anos 1990. Nos créditos do documentário Expedito, além de sua contribuição com depoimentos, o Pe. Ricardo Rezende, que desde 1996 passou a 
habitar o Rio de Janeiro, onde ingressou como docente na UFRJ, também aparece como integrante da produção, argumento, consultoria e pesquisa do filme.

A atuação do Pe. Ricardo faz o projeto de "resgate das lutas sociais dos trabalhadores do campo" (NOVAES, 2017, s/p) constituído por Beto Novaes e Aída Marques se conectarem a estratégias de salvaguarda e divulgação das memórias da luta pela terra desenvolvidas desde os anos 1980 pela CPT e, em especial, pelo próprio padre, autor de diversos livros e integrantes da equipe de outras produções audiovisuais que se propunham a apresentar as ações desenvolvidas pela CPT na região amazônica, a exemplo do documentário Igreja dos Oprimidos, de 1986.

No referido documentário, onde é apresentado como um dos personagens centrais na atuação da Igreja, sob inspiração da teologia da libertação no Sul do Pará, o Pe. Ricardo Rezende expôs didaticamente aos espectadores, o projeto atribuído pela CPT em relação a preservação da memória da luta dos trabalhadores do campo:

Nós trabalhamos às margens do Rio Araguaia, que desemboca no Rio
Amazonas. Aqui nós temos Marabá, São Félix do Araguaia. O
regional da Comissão Pastoral da Terra Araguaia-Tocantins abrange o
norte do Goiás, o norte do Mato Grosso e o sul do Pará. A área é de
570 mil km². É uma área de grande quantidade de conflitos, porque
junto com essa população de migrantes veio junto também grandes
projetos agro-econômicos nacionais e estrangeiros. Nós temos, por
exemplo, no município de Xinguara, perto do Grande Projeto Carajás,
trinta conflitos coletivos; Redenção, seis; Rio Maria, quatro;
Conceição do Araguaia, nove. Em toda região existem muitos
conflitos. Nós prestamos uma assessoria aos trabalhadores rurais no
nível de assessoria jurídica, acompanhamento no movimento sindical,
acompanhamento no nível da fé e também na documentação dos
conflitos. Há uma preocupação grande de se preservar e de se
guardar a história da luta desses trabalhadores. (IGREJA DOS
OPRIMIDOS, 1986, 46-48min, grifo nosso).

No cerne das estratégias adotadas, tais lugares de memória (NORA, 1994) passavam a ser instituídos não somente com o intuito de reunir um conjunto de dados sobre a luta dos trabalhadores rurais, mas sobretudo como informações que poderiam ser acionadas e substanciar outras ações junto a órgãos nacionais e internacionais, visando dar maior visibilidade, pressionar as autoridades e sensibilizar setores progressistas da sociedade brasileira (a exemplo da classe artísticas, intelectual e política) e a comunidade internacional frente aos abusos ocorridos no campo e a impunidade constantemente gozada pelos mandantes dos crimes.

É interessante observar que no já citado documentário Igreja dos Oprimidos, ocorre, precisamente no minuto vinte e cinco, aquilo que Ferro (2010) denomina como 
lapso, uma porção de inesperado, de involuntário, que acaba revelando algo sobre a sociedade retratada que não estavam entre os objetivos iniciais do diretor da obra. Durante o referido minuto, onde é apresentada uma missa rezada pelo Pe. Ricardo Rezende a céu aberto, junto aos camponeses, aparece (imagem acima) um homem negro, fitando diretamente o padre, que naquele momento falava sobre as ações que os latifundiários estavam promovendo na região, com o auxílio de pistoleiros. Aquele homem era Expedito, cuja face aparece de relance. Expedito, que seis anos depois seria alvo das mesmas mazelas denunciadas durante aquela cerimônia.

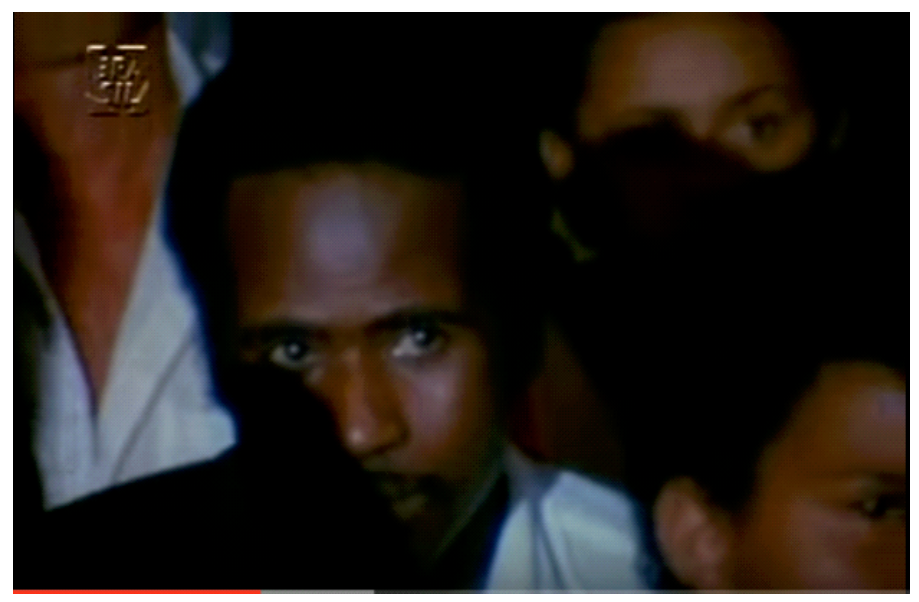

Figura 01: Expedito assiste a missa com o Pe. Ricardo Resende (1985) Fonte: Documentário "Igreja dos oprimidos" (1986).

A forma de atuação frente a memória da luta camponesa e o modus operandi apresentado acima através da fala do Pe. Ricardo Rezende no documentário Igreja dos Oprimidos colabora com a tese levantada por Pessoa, para quem a CPT e os agentes de pastoral que atuavam nas CEBs:

foram muito mais do que mediadores de conflitos ou uma espécie de "retaguarda" política, jurídica e de comunicação dos camponeses. Os espaços como as igrejas, associações e comunidades se transformavam em espaços de reuniões, troca de ideias e experiências. As parábolas e passagens da Bíblia eram reinterpretados pela realidade de quem vive os problemas da terra, numa dimensão míticoreligiosa. $O$ sentido de comunidade era reinterpretado como pertencimento a uma classe, e a partilha, como sinônimo de igualdade. O irmão era o companheiro de luta, dando um sentido de solidariedade que se exacerbava no enfrentamento com o diferente: o fazendeiro, o pistoleiro, o policial, o juiz (2014, p. 82).

Em 2008, quando da publicação da segunda edição do livro Rio Maria: Canto da Terra, constituído a partir do diário que cobre o recorte temporal entre o início do 
seu período de atuação como pároco em Rio Maria e o período imediatamente após o assassinato de Expedito (1988-1991), o Pe. Ricardo expôs que:

Hoje, meu lugar social não é o mesmo. Continuo padre e preocupado com os direitos humanos, mas, desde 1997, vivo no Rio de Janeiro, dou aulas e faço pesquisas. No entanto, apesar disso, mantenho vínculos com o sul do Pará e com o movimento social. Assim, meu apoio aos trabalhadores rurais do Pará se dá por meio de estudos, textos, documentários, visitas à região e articulação de solidariedade. (FIGUEIRA, 2008, p. 21, grifo nosso).

É importante observar que, em conjunto com os projetos acima apresentados que orientaram a participação de Aída Marques e Beto Novaes na direção do filme, o documentário se insere também no projeto de memória ligado não somente a atividade individual do Pe. Ricardo Rezende, embora seja ele um dos seus principais expoentes, mas uma continuidade de ações a partir de lugares de memória instituídos em relação a luta camponesa no Sul do Pará e em outros espaços do Brasil por parte da CPT.

Estratégias, inclusive, que possibilitaram o acionamento de um arquivo sobre Expedito composto no início dos anos 1990, juntando os rastros de sua trajetória em vida à representação do legado poético e político (onde estas duas dimensões estiveram fortemente imbricadas) por ele deixado. Cumpre destacar que tais estratégias também influenciam não somente a formação de um arquivo e seleção no interior desse arquivo, mas também parte das formas como esse arquivo foi acionado durante a elaboração do filme. Arquivo este que foi se ampliando com a repercussão gerada pelo assassinato de Expedito e a criação dos Comitês Rio Maria. Entre esses comitês está o Comitê Rio Maria do Rio de Janeiro, que apresentam o documentário Expedito, juntamente com a produtora MP2, ligada a Aída Marques.

\section{Poéticas da memória e da violência}

Um dos principais recursos utilizados no documentário são os depoimentos de familiares e pessoas próximas a Expedito. Através desses relatos, o personagem Expedito vai sendo lentamente tecido junto ao expectador, por intermédio de cada recordação evocada, cada lembrança apresentada por aqueles que conviveram com ele antes ou durante o seu período de atuação no STR de Rio Maria. Somam-se a estes depoimentos a apropriação de trechos de vídeos que vão desde registros audiovisuais de entrevistas ou depoimentos dados pelo próprio Expedito durante a sua peregrinação 
feita pouco antes da sua morte para denunciar os crimes e o contexto de impunidade vigentes no Sul do Pará, até trechos de documentário utilizado como propaganda do governo militar sobre a Transamazônica, apresentando-se o contraste dialético entre a representação da vida dos colonos constituída pela propaganda oficial e a experiência enfrentada na região Amazônica por Expedito e seus familiares; ou ainda recortes do filme Outubro, do cineasta soviético Serguei Eisenstein (1898-1948).

A obra clássica de Eisenstein, produzida em memória aos dez anos da Revolução Russa, é reconhecida não somente por desenvolver uma relação entre cinema e história, mas pela apuração estética, que dá tom a uma poética da violência, como apontado por Rocha (2003). Essa poética é aludida sutilmente no filme Expedito, através da apropriação da imagem de rodas de bicicleta retiradas de Outubro, que surge vez ou outra, apresentando cortes na linearidade das narrativas, como que remetendo metaforicamente a passagem do tempo; e apresentada junto aos giros de uma roda de bicicleta contemporânea a produção do documentário, analogia não somente a passagem do tempo, mas também ao meio de transporte utilizado por Expedito para percorrer Rio Maria durante a campanha para vereador em 1986.

A apropriação de Eisenstein também sinaliza o cuidado com a narrativa que está sendo apresentada, possibilitando ao espectador a leitura de que não se trata apenas de um amontoado de depoimentos meramente dispostos na ordem de sua importância numa sequência linear do nascimento à morte do sindicalista, ainda que seja esse o caminho trilhado pela narrativa principal, mas sim uma produção movida por escolhas, cortes e recortes. Desse modo, interessa observar que a apropriação de Eisenstein não ocorrer por acaso, fazendo referência ao ritmo e poesia com que a trama vai sendo tecida e a forma como o personagem Expedito é construído, e sua trajetória vai sendo documentada e, como consequência, monumentalizada, no cerne de lutas de representação sobre os conflitos no campo brasileiro.

Quanto as narrativas apresentadas pelos familiares de Expedito, ganha destaque no início do documentário a exposição de memórias tidas pelo seu irmão Arcângelo e por suas irmãs Isabel, Eva, Benedita e Agda. Tais relatos, além de tratarem de pontos relevantes sobre a origem do sindicalista, e apresentarem elementos curiosos sobre alguns episódios que cercaram sua infância, ajudam também a tornar visível os trajetos percorridos pelos seus familiares, que em busca da manutenção de sua subsistência no espaço do campo, migraram do interior de Minas Gerais rumo a estados como Baía, Espírito Santo, Goiás, Tocantins e Pará. Tais migrações acabaram distanciando uns dos 
outros os pais, irmãos, primos e outros parentes de Expedito, tornando precisa a compreensão apresentada por Figueira (2004, p. 286): “A vida dos migrantes é preenchida por deslocamentos geográficos e afetivos".

Os deslocamentos de Expedito e seus familiares, inserem-se numa cartografia migrante que faz referência a um contexto onde milhares de pessoas seguiram para a região Amazônica em busca de outros nortes. Pessoas que viveram experiências que no universo da cultura camponesa, pautada pela oralidade, permitem-lhes assumir um lugar de autoridade para transmitir às outras gerações o que vivenciaram, como é bem representado pela frase de Arcângelo, irmão mais velho de Expedito, que encerra o documentário: "Mas essa é a nossa história. Essa é a história nossa, do meu tempo pra cá. Desde aquela época que eu me entendia por gente. Essa foi a história da minha família." (EXPEDITO, 2007, 1h13min). Esse relato reinsere o que foi narrado sobre Expedito, sindicalista e poeta, dentro de experiências familiares, e no cerne de vivências compartilhadas coletivamente, e recoloca ainda o papel atribuído a função do narrador durante a exteriorização das memórias. Como num gesto benjaminiano, é creditado novamente ao narrador a recomposição de acontecimentos que por si só se esfacelariam e se perderiam no tempo não fosse o gesto, profundamente inserido na cultura camponesa, de cultivar a rememoração, que funda a cadeia da tradição ao transmitir "os acontecimentos de geração em geração" (BENJAMIM, 2012, p. 228).

O documentário evoca assim a experiência e a autoridade do narrador, buscando reconectar a aceleração e a reprodução técnica do ver, à reflexividade do ouvir. Para Benjamim, essa autoridade é sancionada pelo advento da morte: "A morte é a sanção de tudo o que o narrador pode relatar. É da morte que ele deriva sua autoridade" (2012, p. 224). É sobre o corpo morto de Expedito, tombado precocemente pelo latifúndio, que se sustenta a firmeza da narrativa de seu irmão mais velho, guardião da memória da família. É sobre uma morte que ajudou a reconectar irmãos separados pelo destino migrante, que essa autoridade se reafirma; e é sobre a notícia de uma morte, noticiada pela televisão em rede nacional numa noite de domingo, que a especificidade do vivido realça seus contornos próprios, e a condição da oralidade como insubstituível fonte de transmissão de saberes é mesclada com o recurso da veiculação rápida de informações e perpetuação possibilitada pelo audiovisual.

Sobre a especificidade de como soube da morte de seu irmão e, por extensão, de seu pai e destino de outros parentes, Arcângelo narra: 
aí eu já tinha certeza que era o Expedito, não é. Ela falou comigo assim: "bibi". "O que você veio fazer aqui?"; e ela, "eu já sei". "O Expedito lá no sul do Pará, não é? Eu já sei". "Dito certo." Ela falou "dito certo". E "eu vim chama ocê pra nós ir lá buscar a mãe, que a mãe tá doente". Aí eu fui lá... não sabia nem que o pai dele [ponta para um sobrinho seu e de Expedito, localizado por trás da câmera] era falecido não. Nem sabia que o vei, meu pai também, era falecido. Sabia não. Recebi as três notícias numa hora só. Assim mesmo disso tudo, que meu era falecido, o pai dele e do... do Expedito e do meu pai. Recebi essas três notícias numa hora só. Fui no outro mundo e voltei [emoção] [choro] (EXPEDITO, 2007, 56min).

Por meio de sua narrativa, Arcângelo nos ajuda a ter contato com memórias de um percurso outrora esfacelado, que vai se recompondo e tornando inteligíveis à medida que alguns acontecimentos vão sendo narrados. Percurso que se reconecta inicialmente quando do contato com a notícia do paradeiro e da morte do irmão e posteriormente através dos reencontros e gestos memorialísticos que esse acontecimento traumático engendra, e que é ressignificado pelos diretores, novamente colocando a experiência em tela. No documentário Expedito, a experiência do narrador, a importância do gesto de rememoração e a apresentação da visão de mundo camponesa são expressas no cerne de diversos depoimentos ligados aos familiares de Expedito, como aquele em que, em sentido inverso do que é apresentado acima, o nascimento de Expedito e o motivo da escolha de seu nome são narrados nas palavras de sua irmã Agda:

E quando ele nasceu, minha mãe conta que ele nasceu com seis quilos. Era um menino muito... Era predestinado. O nome dele foi promessa, o nome dele... Foi promessa, que minha mãe tinha oito dias que tava passando mal pra ganhar ele. Aí falaram assim, quase cinco horas chamaram a Maria e aí falaram assim, meu pai chorava e falava assim: "esse não nasce não. Esse aí vai morrer a mãe e o filho" [pai]. E a mulher falou assim "não, João, vai atrás da Dona Maria". Ele foi buscar de cavalo mais de cinco horas. Minha mãe conta, contava, que era uma velhinha magra e aí quando ela chegou, ela entrou. Aí ela gritou assim "Ah, são Expedito, ajuda nessa hora de causa urgente, meu senhor" [Maria]. Bateu o joelho no chão e levantou. As mãos para cima, assim [olhando para cima] e fez uma oração [pausa] ele nasceu. Era predestinado sim (EXPEDITO, 2007, 3-4min).

Os depoimentos são em geral apresentados nos espaços internos ou próximos as residências dos entrevistados, que podem se configurar inclusive como um barracão no interior de um acampamento do Movimento dos Trabalhadores Sem-Terra (MST), como ocorre com Agda, irmã de Expedito, dando um tom mais familiar as memórias narradas. Aos poucos, essas memórias vão se ampliando para além do ciclo familiar de 
Expedito e passam a remeter a sua atuação cotidiana, como sindicalista, agente de pastoral e poeta. Como relembra Luzia Canuto, filha de João Canuto, presidente do STR de Rio Maria, assassinado em 1985, a poesia tinha papel fundamental no cotidiano e na atuação política e religiosa de Expedito:

O Expedito e meu pai trabalharam juntos em algumas terras de pequenos e médios proprietários. É... Cantavam muito, né, alguns hinos da igreja que a gente percebe assim, eu falava da questão da justiça, falava da questão da igualdade... Também o Expedito era uma pessoa, assim, que amava a natureza. A gente percebia que nas nossas atividades políticas ou religiosas, o Expedito, as vezes ele roubava a cena de todo mundo, né, com as suas poesias (EXPEDITO, 2007, 26min).

Assim como Luzia Canuto, Antônia, filha de Expedito, também rememora a inserção da poesia no cotidiano do pai:

Todas as vezes quando ele vinha a noite, de tardezinha, que ele sempre chegava a noite do sindicato, eu ia pra esquina esperar ele lá. ai ele pegava a cadeirinha, né, o taburete que chama aqui, taburente e ia pra de baixo do posto pra poder escrever as poesias dele. Lá de baixo... (EXPEDITO, 2007, 26min).

Já o poeta Inácio Barbosa, cuja a inserção no documentário, é importante frisar, não se dá por mero acaso, mas para tornar mais visível a compreensão da importância da poesia no dia-a-dia e mesmo nas relações de sociabilidade traçadas por Expedito, rememora seus primeiros contatos e diálogos com o sindicalista:

Expedito Ribeiro de Sousa eu conheci, a primeira vez, o Expedito... eu conheci ele sem ter contato com ele, vendo ele. Depois eu passei a ter contato com ele de palestra, inclusive eu tive assistindo missa na igreja católica e ele era um dos que faziam parte das páginas de leitura da missa. Então eu observei que ele fosse uma pessoa dali. Então aí depois descobri que ele tralhava no sindicato dos trabalhadores rurais de Rio Maria e fui vendo que ele era uma pessoa de boa personagem, que era um bom amigo, uma pessoa entendida. Então a gente falava sobre movimentos populares (EXPEDITO, 2007, 25min).

É mister observar que o esforço memorialístico que envolve o sindicalista após sua morte não era estranho ao próprio Expedito, que em seu livro de poemas $O$ canto negro da Amazônia, reuniu poemas laureando a memória de pessoas que haviam tombado na luta pela terra. São elas: Poesia em homenagem a Chico Mendes, Homenagem ao Bravo combatente Paulo Fonteles! e Homenagem ao João Canuto. 
O livro de Expedito referido acima foi publicado pelo Núcleo de Altos Estudos Amazônicos (NAEA) da Universidade Federal do Pará, após a sua morte, a partir dos originais submetidos por ele junto a concurso promovido em Belém pela Fundação Cultural Trancredo Neves. Do referido livro, constituídas por poesias próxima a linguagem do cordel, foi extraído o subtítulo do documentário, Em busca de outros nortes, integrante do poema intitulado Poesia Popular de Expedito Ribeiro de Souza:

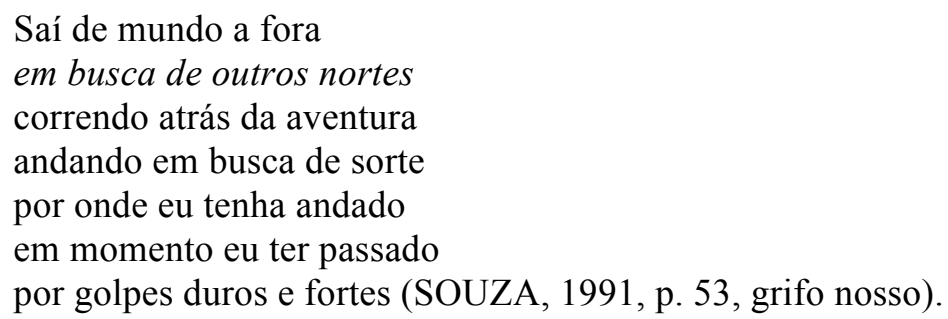

No documentário, esse trecho e outros do mesmo poema, e dos poemas Homenagem ao Rio Maria e $O$ silêncio são apresentados durante partes do filme, com destaque para o início e final, na voz cantor, compositor e escritor Chico Buarque de Holanda. De acordo com Napolitano (2010, p. 282), durante a análise histórica de um filme, devemos identificar "os elementos narrativos ou alegóricos da encenação do filme a partir de planos e sequências, técnicas de filmagem e narração, elementos verbais, imagéticos e musicais". A participação de Chico Buarque e os usos da poesia de Expedito no cerne da obra nos fazem buscar compreender como as escolhas estéticas do filme interagem com a constituição da narrativa que ele apresenta, voltada para a trajetória de vida do seu protagonista e sua relação com a luta pela terra. Aqui, o cantor, compositor e escritor Chico Buarque tem papel não somente de emprestar seu prestígio a obra, mas de nos lembrar de Expedito como um poeta vinculado a uma poética engajada e compromissado com a mudança social.

\section{A construção da imagem do mártir da terra}

No decorrer da construção da narrativa do documentário, vão se adensando as imagens sobre os lugares sociais ocupados em vida por Expedito. Completada a apresentação da trajetória migrante de sua família, e introduzida sua produção poética e sua atuação política, começa a ganhar corpo a constituição de uma outra imagem, que vai se delineando à medida que a narrativa passa a tratar da atuação de Expedito na 
condição de ameaçado de morte. Nesse momento, são apresentadas memórias como a do já citado poeta Inácio Barbosa:

ele foi lá em casa e eu conversando com ele disse: “- Expedito, mas você não tem medo de ocê ser sequestrado e morto a qualquer hora? Você já viu os exemplos dos outros, porque já tinham matado Brás, o Ronan, o Canuto...". "Olha [respondeu Expedito], antes disso eu tinha medo, mas agora que a justiça descobriu e sabe eu não tenho mais medo não. Mas se acaso eu morrer, que seja a vontade de deus. Morre eu, mas a história fica". Me lembro como se fosse hoje ele dizendo isso: "- Morre eu, mas a história fica" (EXPEDITO, 2007, 38min).

As opções tomadas por Expedito frente a sua "morte anunciada" são retratadas no documentário a partir de uma visão que era compartilhada pelo próprio sindicalista, vinculada a concepção de martírio, inserida num contexto de articulação entre fé e política, num contexto marcado pela ameaça aos trabalhadores rurais e as suas lideranças nos sindicatos. Inicialmente, são apresentados relatos que inserem a atuação de Expedito dentro de uma lógica cristã, como no depoimento de sua filha Antônia, onde as ações do pai são justificadas pela concepção de "Amor ao próximo":

meu pai fazia tanta coisa ajudava, levava as pessoas doentes pra tratar. A pessoas chegava e não: "- Tá acontecendo assim, assim, assim, assim eu preciso da sua ajuda". Meu pai estava ali sempre disposto a ajudar. Ai em troca meu pai não ganhava nada, né, não ganhava dinheiro. Meu pai não tinha emprego fixo, né, a minha família chegou muitas vezes a passar fome, ne, e eu me perguntava "Meu deus do céu, como é que pode?" Meu pai não trabalha e fica ajudando essas pessoas, né, e a gente passa as necessidades em casa e tudo mais. Existe uma explicação pra tudo isso, né, que eu deduzi que seria o amor ao próximo, né, e quando eu comecei a entender isso eu passei a trabalhar com ele, né, eu trabalhava no sindicato eu era secretária dele. Secretária, mas não pelo salário, porque não tinha como pagar salário (EXPEDITO, 2007, 28min).

Essas visões são articuladas as próprias concepções de Expedito, que demonstra ter uma leitura aprofundada da dinâmica que regia os conflitos de terra naquele momento; conflitos em que ele próprio, na condição de presidente do STR Rio Maria, estava envolvido e que foram por ele denunciado à exaustão, inclusive em vídeos, rastros que viriam a ser apropriados pelos diretores do documentário. Em um deles, Expedito narra os assassinatos de Brás, Ramon, José Canuto e Paulo Canuto: 
Essa aqui é a foto de Brás e de Ramon, né, dois companheiros nosso que foram assassinados em Rio Maria no dia 03 de abril, foi sequestrado na casa deles, porque eles dois era mecânico e eles usaram convidaram eles pra consertar um carro, né. O carro estava distante de Rio Maria $20 \mathrm{~km}$. Eles vieram consertar o carro e, no entanto, passou a noite e eles não chegaram. Non outro dia, oito horas da manhã, nós encontramos eles dois, né, que tava morto no meio de uma estrada lá. É a chacina que houve foi justamente a dos irmão Canuto, né. É José Canuto e Paulo Canuto, filho de João Canuto, né. Os caras chegou dizendo ser da polícia federal e sequestrou eles e levaram lá pra um estrada lá que tem né, que liga Rio Maria à Marabá, que é a PA 150 e lá assassinou o Zé e o Paulo. O Orlando que escapou que hoje tá e Belém em tratamento em Belém ele afirmou que os caras iam levar eles, iam fazer a chacina deles, ia matar eles, voltava pra me buscar e buscar um outro, né, que era Carlo, o secretário do Sindicato. Então eles iam voltar pra me buscar eu que sou o presidente do sindicato e o Carlos, que era o Secretário. Tinha pegado eles, mas voltava pra pegar mais (EXPEDITO, 2007, 34-35min).

Pouco depois do detalhamento de sua morte, é reproduzida um trecho de depoimento de Expedito que ele apresenta suas expectativas quanto a punição em relação aos crimes cometidos em Rio Maria. O relato é apresentado não somente em relação aos crimes até então cometidos, mas o registro audiovisual é apropriado de modo que a Explicação dada por Expedito é utilizada para lançar sua visão sobre o contexto em que sua própria morte está inserida, como se além de sua morte, já estivesse também anunciada a impunidade ao mandante do crime:

eu acho o seguinte: essa prisão decretada eu não tenho fé porque muitas vezes decretam as prisão e não prende e isso aí acontece porque os caras são poderosos. Vão entrar com recurso, vão entrar com advogado e acabar não indo para a cadeia. O máximo que se prender é um ou dois pistoleiros, né, os que fizeram o crime. Mas os fazendeiros eu não tenho fé que eles vão para a cadeia, não. Porque lá já aconteceu muitas vezes de ser decretada prisão preventiva para mandantes e eles não são presos (EXPEDITO, 2007, 1h1min1h2min).

A permanência de Expedito na luta, mesmo frente a iminência da morte, é trabalhada em detalhes pelo documentário, que rendilha aos poucos uma concepção de sacrifício, que vincula o sindicalista aos mártires da terra e da caminhada, designações mantidas inicialmente por grupos da Igreja ligados as CEBS e a teologia da libertação, e que passam a dar o tom a organização das memórias de lideranças vitimadas pelos conflitos no campo, a nível local, nacional e internacional. Expedito, em especial em 
iniciativas dessa ordem realizadas no Sul do Pará, é um dos mártires lembrados, ganhando destaque também em publicações a nível nacional e no âmbito da América Latina em publicações vinculadas a Irmandade dos Mártires da Caminhada ${ }^{5}$.

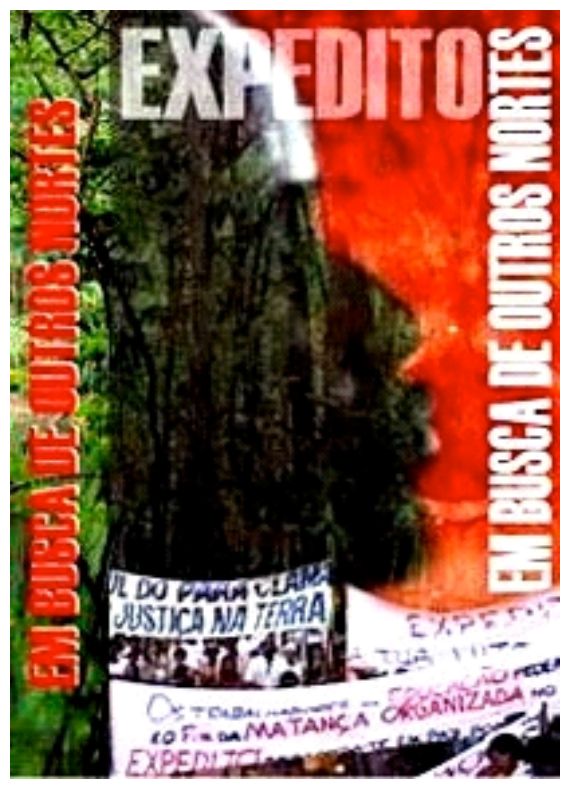

Figura 02: Cartaz de divulgação do filme Expedito

Disponível em: https://filmow.com/expedito-embusca-de-outros-nortes-t31761/

No documentário, cumpre papel importante para a construção da imagem do mártir a apresentação do cadáver de Expedito, logo após o seu assassinato. Com essa exposição, os diretores não somente apresentam o registro sobre a condição brutal da morte de Expedito, que fora bastante explorada em fotografias e reportagem à época, sobretudo porque pouco antes de ser morto, Expedito havia dado entrevista ao jornal Le Monde Diplomatique, da França, onde aparecia a legenda "Esse homem vai ser morto".

A exposição contribui também para a composição do que Souza (2013) chama de rituais de sacralização de lideranças populares, parte do processo de sua transformação em mártires. Note-se que além da exposição do corpo desfalecido de Expedito durante o documentário, a imagem também figura na capa da produção, onde a cor preta da pele de Expedito é colocada em contraste com um fundo vermelho, que certamente representa o sangue derramado nos conflitos no campo, e o verde das matas, provável alusão a região amazônica. Também são apresentados cartazes vinculados a

\footnotetext{
${ }^{5}$ Ver perfil de Expedito Ribeiro de Souza e outros "mártires" no sítio da Irmandade dos Mártires da Caminhada: $\quad$ http://irmandadedosmartires.blogspot.com.br/2017/02/galeria-dos-martires-expeditoribeiro.html
} 
luta pela justiça na terra e que vinculam a memória de Expedito à luta contra a impunidade nos conflitos no campo no Pará.

Essa construção não deve ser lida como inocente, mas como vinculada ao que o já citado Souza chama de fabricação social do sacrifício. Souza constatou em sua pesquisa que a imagem e a memória dos mártires contribui para a manutenção da luta no campo, onde mortos e vivos coabitam:

Como os mortos de Pedro Páramo (2008), estes mártires-encantados estão ainda 'presentes na caminhada', tando nas imagens de camisetas e das paredes pelos diversos lugares por onde andei no Mato Grosso, Pará e Pernambuco, quanto nas suas histórias de luta revividas e agenciadas pelas narrativas dos coletivos, tornando-as referência para os que sobreviveram (SOUZA, 2013, P. 19).

Essas considerações a respeito da construção da imagem do mártir da terra e da caminhada, facilitam a interpretação, sem a pretensão de esgotá-la, de algumas escolhas feitas por Aída Marques e Beto Novais durante a construção do documentário e a criação de um lugar de memória sobre a vida de Expedito. Às imagens constituídas pelas memórias de seus familiares, que desde o início do documentário o colocam como um predestinado; e por parte dos amigos, companheiros de luta e depoimentos do próprio Expedito, que ajudam a explicar melhor o contexto em que ele viveu, somam-se a apresentação da escolha feitas por ele: Por que não desistir? Por que não ir embora de Rio Maria? Por que não fugir da morte anunciada?

Ao tratar da vida e do legado de Expedito, o filme contribui para a composição de um monumento que ajuda a divulgar experiências vivenciadas na luta pela terra que precisam ser rememoradas, para que seja dado o devido enfrentamento a continuidade das chacinas e impunidade seus aos mandantes. Ao ver o corpo do mártir e ao rememorar sobre a sua trajetória, numa lógica bastante enraizada no próprio cristianismo, aqueles que continuam a sua luta podem se sentir revigorados e inspirados pelos exemplos por ele apresentados em vida. Exemplos esse de enfrentamento da morte em conflitos no campo que não cessam de surgir no Sul e Sudeste do Pará.

Em 2017, durante o período de finalização deste artigo, mais uma chacina assolou o Sul do Pará. No município Pau D’arco, que faz fronteira com Rio Maria, dez camponeses foram brutalmente assassinados por policiais militares, no maior massacre após Eldorado dos Carajás (1996). Em momentos como o atual, de reavivamento de chacinas, massacres e acirramento dos conflitos no campo no Pará, em Mato Grosso e em outros estados brasileiros, tornar-se importante relembrar a figura de Expedito, 
assim como compreender como são constituídas as imagens em torno de sua atuação política. Tais rememorações podem contribuir, como pode ser vislumbrado na obra dirigida por Aída Marques e Beto Novaes, para a tessitura de um contexto em que semterra, indígenas, quilombolas e outros sujeitos do campo e da cidade não assistam a todo o tempo à criação de novos mártires. Esse contexto, como nos faz lembrar Expedito, certamente se configura um importante norte a ser buscado.

\section{REFERÊNCIAS}

AUMONT, Jacques; MARIE, Michel. Dicionário teórico e crítico do cinema. Campinas: Papirus, 2003.

BENJAMIM, Walter. O narrador: considerações sobre a obra de Nikolai Leskov. In: Magia e técnica, arte e política, I: ensaios sobre literatura e história da cultura. São Paulo: Brasiliense, 2012. p. 213-240.

BOFF, Leonardo. Quarenta anos da Teologia da Libertação. Disponível em: $<$ https://leonardoboff.wordpress.com/>. Acesso: abr. 2017.

CHARTIER, Roger. A História Cultural: entre práticas e representações. Lisboa: Difel; Rio de Janeiro: Editora Bertrand Brasil, 1990. 239 p.

EXPEDITO em busca de outros Nortes. Direção: Aída Marques e Beto Novaes. Produção: Aída Marques, Beto Novaes, Ricardo Rezende e Adonia Prado. Rio de Janeiro. MP2. Disponível em: $<$ https://www.youtube.com/watch?v=rH45C_1JZ7o $>$. Acesso: ago. 2016.

FEITOSA, Terezinha Cavalcante. Questão Agrária, violência e poder público na Amazônia brasileira: o Assassinato do líder sindical João Canuto de Oliveira. 2011. 269 p. Tese (Doutorado em Ciências Sociais em Desenvolvimento, Agricultura e Sociedade), Universidade Federal Rural do Rio de Janeiro. Rio de Janeiro.

FERNANDES, Marcionila. Biografia. In: SOUZA, Expedito Ribeiro de. O canto negro da Amazônia. Belém: Falange editora, 1991. p. 9-11.

FIGUEIRA, Ricardo Rezende. A justiça do lobo: posseiros e padres do Araguaia. Petrópolis: Vozes, 1986.

Pisando fora da própria sombra: a escravidão por dívida no Brasil contemporâneo. Rio de Janeiro: Civilização Brasileira, 2004.

. Rio Maria: canto da terra. Rio de Janeiro: Civilização Brasileira, 2008.

FERRO, Marc. Cinema e História. Tradução Flávia Nascimento. São Paulo: Paz e Terra, 2010.

GAGNEGIN, Jeanne Marie. Verdade e memória do passado. Proj. Historia, São Paulo, n. 17, p. 213-221, nov. 1998.

IGREJA dos Oprimidos. Direção: Jorge Bodanzky. Produção: Lucíola Vilella. Argumento: Helena Salem. 1986.

LE GOFF, Jacques. Documento/Monumento. In: História e memória. Tradução Bernardo Leitão et al. 5. ed. Campinas: Editora da UNICAMP, 2003. p. 525-541. 
MARQUES, Aída Maria Bastos Nepomuceno. Currículo do sistema currículo Lattes. [Brasília], 30 jan. 2017. Disponível em: <http://lattes.cnpq.br/2966583998288427>. Acesso em: 26 fev. 2017.

MORETTIN, Eduardo. O cinema como fonte histórica na obra de Marc Ferro. In: CAPELATO, Maria Helena et al. História e Cinema: Dimensões Históricas do Audiovisual. 2. ed. São Paulo: alameda, 2011. p. 39-64.

NAPOLITANO, Marcos. Fontes audiovisuais: a história depois do papel. In: PINSKY, C. B. (org.). Fontes Históricas. 2. ed. São Paulo: Contexto, 2010. p.. 235-290.

NORA, Pierre. Entre memória e história: a problemática dos lugares. Projeto História, São Paulo, n. 10, p. 7-28, 1993.

NOVAES, José Roberto Pereira. Currículo do sistema currículo Lattes. [Brasília], 29 abr. 2015. Disponível em: <http://lattes.cnpq.br/2966583998288427>. Acesso em: 26 fev. 2017.

OLIVEIRA FILHO, Moacyr. Rio Maria: a terra da morte anunciada. São Paulo: Editora Anita Garibaldi, 1991.

PEIXOTO, Rodrigo. Ação cultural e concepção política entre a Igreja Católica e os camponeses (um estudo na região de Marabá). In: LENÁ, Philippe; OLIVEIRA, Adélia Engrácia de (Org.). Amazônia: A fronteira agrícola 20 anos depois. Belém: Museu paraense Emílio Goeldi, 1991. p. 145-160.

PESSOA, Fabio Melo. Bispo comunista, padres subversivos: cristianismo de libertação e a luta camponesa no sul do Pará durante o período militar. Outros Tempos, São Luís, v. 11, p. 61-82, 2014.

ROCHA, Glauber. Revisão crítica do cinema brasileiro. São Paulo: Cosac \& Naify, 2003.

SILVA, Idelma Santiago. Migração e cultura no Sudeste do Pará: Marabá (19681988).2006. 181f. Dissertação (Mestrado em História) — Universidade Federal de Goiás, Goiânia, 2011.

SOUZA, Expedito Ribeiro de. O canto negro da Amazônia. Belém: Falange editora, 1991.

SOUZA, Edmilson Rodrigues de. A morte sobre outro ponto de vista: transformação do líder-morto em mártir encantado. 2007. 137 f. Dissertação (Mestrado em Ciências Sociais), Universidade Federal do Espírito Santo. Centro de Ciências Humanas e Naturais. Vitória. 